\title{
Accumulation of nutrients and agronomic performance of grafted seedless watermelon ${ }^{1}$
}

\author{
Joice Simone dos Santos², Rita de Cássia Souza Dias ${ }^{3}$, \\ Leílson Costa Grangeiro ${ }^{2}$, Welson Lima Simões ${ }^{3}$, Magnus Dall'Igna Deon ${ }^{3}$
}

\begin{abstract}
Chemical fertilizing is one of the main inputs that increase watermelon production costs. Watermelon grafting with compatible rootstocks and a vigorous root system may increase the efficiency of nutrients absorption. This study aimed at determining the accumulation of dry matter and nutrients, as well as the agronomic performance of grafted watermelon. The triploid 'Precious Petite' watermelon was used as graft and the Line BGCIA941 (Citrullus lanatus var. citroides) as rootstock. The experimental design consisted of randomized blocks, in a split-plot, with six replicates. The 'Precious Petite' grafted onto Line BGCIA941, ungrafted 'Precious Petite' and ungrafted Line BGCIA941 were evaluated in the plot, while the subplot corresponded to the sampling time $(0,10,20,30,40,50,60$ and 70 days after transplanting). 'Precious Petite' grafted onto Line BGCIA 941 accumulated more macro and micronutrients than the ungrafted plants, increasing fruit yield, flesh firmness and rind thickness, but it did not affect the soluble solids contents. The decreasing order for nutrient accumulation in the grafted plants was $\mathrm{N}>$ $\mathrm{K}>\mathrm{Ca}>\mathrm{Mg}>\mathrm{P}>\mathrm{S}>\mathrm{Fe}>\mathrm{Mn}>\mathrm{Zn}>\mathrm{B}>\mathrm{Cu}$, whereas for ungrafted 'Precious Petite' it corresponded to $\mathrm{N}>\mathrm{K}>\mathrm{Ca}>$ $\mathrm{Mg}>\mathrm{P}>\mathrm{S}>\mathrm{Mn}>\mathrm{Fe}>\mathrm{B}>\mathrm{Zn}>\mathrm{Cu}$.
\end{abstract}

KEY-WORDS: Citrullus lanatus; nutrient uptake; plant nutrition.

\section{INTRODUCTION}

Mineral nutrition is one of the factors that contribute directly to the yield and quality of watermelon fruits (Barros et al. 2012). Watermelon is relatively demanding in primary (nitrogen, phosphorus and potassium) and secondary macronutrients (calcium, magnesium and sulfur), and benefits from the micronutrients application. These nutritional demands may be suppressed by

\section{RESUMO}

Acúmulo de nutrientes e desempenho agronômico de melancia sem sementes enxertada

A adubação química é um dos principais insumos que aumentam os custos de produção da melancia. Aenxertia de melancia em porta-enxerto compatível e com sistema radicular vigoroso pode aumentar a eficiência na absorção de nutrientes. Objetivou-se determinar o acúmulo de massa seca e de nutrientes e o desempenho agronômico em melancia enxertada. Utilizou-se como enxerto a melancia triploide 'Precious Petite' e como porta-enxerto a Linha BGCIA941 (Citrullus lanatus var. citroides). O delineamento experimental foi em blocos casualizados, em parcela subdividida, com seis repetições. Na parcela, avaliou-se 'Precious Petite' enxertada na Linha BGCIA941, 'Precious Petite' sem enxertia e Linha BGCIA941 em pé franco, enquanto a subparcela correspondeu à época de amostragem $(0,10,20,30,40,50,60$ e 70 dias após o transplantio). 'Precious Petite' enxertada na Linha BGCIA 941 acumulou mais macro e micronutrientes que as plantas sem enxertia, incrementando a produtividade de frutos, firmeza da polpa e espessura da casca, mas não alterou os teores de sólidos solúveis. A ordem decrescente de acúmulo de nutrientes nas plantas enxertadas foi $\mathrm{N}>\mathrm{K}>\mathrm{Ca}>\mathrm{Mg}>$ $\mathrm{P}>\mathrm{S}>\mathrm{Fe}>\mathrm{Mn}>\mathrm{Zn}>\mathrm{B}>\mathrm{Cu}$, e em 'Precious Petite' sem enxertia correspondeu a $>\mathrm{K}>\mathrm{Ca}>\mathrm{Mg}>\mathrm{P}>\mathrm{S}>\mathrm{Mn}>\mathrm{Fe}>\mathrm{B}>\mathrm{Zn}>\mathrm{Cu}$.

PALAVRAS-CHAVE: Citrullus lanatus; absorção de nutrientes; nutrição de plantas.

equilibrated doses of fertilizers into the soil at sowing or as proper topdressing. The absorption of nutrients differs according to plant development, and is higher at flowering, setting and fruit growth.

When watermelon is grafted with a compatible rootstock, and a vigorous root system is adopted, the plants absorb nutrients more efficiently than ungrafted plants (Pulgar et al. 2000, Lee et al. 2010). Watermelon grafts are used in $95 \%$ of its cultivation areas in Japan, Korea and Spain, mainly to control

1. Manuscript received in Jan./2016 and accepted for publication in Sep./2016 (http://dx.doi.org/10.1590/1983-40632016v4639610).

2. Universidade Federal Rural do Semiárido, Departamento de Ciências Vegetais, Mossoró, RN, Brazil. E-mails: joicessm@gmail.com, leilson@ufersa.edu.br.

3. Empresa Brasileira de Pesquisa Agropecuária (Embrapa Semiárido), Petrolina, PE, Brazil.E-mails: rita.dias@embrapa.br, welson.simoes@embrapa.br, magnus.deon@embrapa.br. 
soil pathogens, such as fusarium wilt (Yetisir \& Sari 2003, Yetisir et al. 2007). However, over the years, other objectives have become important, such as resistance to low and high temperatures, tolerance to salinity and alkalinity, increase in the absorption of nutrients, efficiency in water use and improvement of fruit yield and quality (Cohen \& Naor 2002, Rivero et al. 2003, Colla et al. 2010, Yetisir \& Uygur 2010, Karaca et al. 2012).

The effects of rootstocks on the absorption, translocation and use of nutrients on plants have been documented in previous studies (Rouphael et al. 2008, Colla et al. 2010, Yetisir et al. 2013). The increase of nutrient absorption in grafted plants may be attributed mainly to the physical characteristics of the root system, such as the vertical and lateral development of the roots, which promote increased absorption of water and inorganic nutrients.

This study aimed at determining the effect of grafting on the accumulation of dry mass, absorption of nutrients and agronomic performance of triploid watermelon.

\section{MATERIAL AND METHODS}

The experiment was performed from June to August (2012), at the Bebedouro Experimental Field ( $9^{\circ} 9^{\prime} \mathrm{S}, 40^{\circ} 29^{\prime} \mathrm{W}$ and altitude of $365.5 \mathrm{~m}$ ), which belongs to the Embrapa Semiárido, in Petrolina, Pernambuco State, Brazil.

The physical-chemical soil analyses of the experimental area showed the following results: sand $=83.60 \%$; silt $=12.25 \%$; clay $($ sandy soil $)=$ $4.15 \% ; \mathrm{pH}\left(\mathrm{H}_{2} \mathrm{O}\right)=6.7$; organic matter $=6.6 \mathrm{~g} \mathrm{dm}^{-3}$; $\mathrm{P}($ Mehlich $)=38.4 \mathrm{mg} \mathrm{dm}^{-3} ; \mathrm{K}=0.3 \mathrm{cmol} \mathrm{dm}^{-3}, \mathrm{Ca}=$ $2.2 \mathrm{cmol} \mathrm{dm}^{-3} ; \mathrm{Mg}=0.7 \mathrm{cmol} \mathrm{dm}^{-3} ; \mathrm{Cu}=0.5 \mathrm{mg} \mathrm{dm}^{-3}$; $\mathrm{Fe}=19.2 \mathrm{mg} \mathrm{dm}^{-3} ; \mathrm{Mn}=12.6 \mathrm{mg} \mathrm{dm}^{-3} ; \mathrm{Zn}=$ $3.3 \mathrm{mg} \mathrm{dm}^{-3}$; electrical conductivity $=0.65 \mathrm{dS} \mathrm{m}^{-1}$; total base $=3.3 \mathrm{cmol} \mathrm{dm}^{-3}$.

The experimental design consisted of randomized blocks, in a $3 \times 8$ split-plot arrangement, with six replications. The following was evaluated in each plot: 'Precious Petite' cultivar grafted onto Line BGCIA 941, ungrafted 'Precious Petite' and Line BGCIA 941 rootstock. In the subplots, the following sampling periods were analyzed: $0,10,20,30,40$, 50,60 and 70 days after transplanting (DAT). The experimental unit consisted of 30 plants per plot.

The triploid 'Precious Petite' watermelon cultivar was used as graft, and the Line BGCIA
941 was adopted as rootstock, originating from the introduction of PI244019 (Citrullus lanatus var. citroides), which is conserved in the Active Cucurbitaceae Germplasm Bank of the Embrapa Semiárido.

The approach grafting method (Cushman 2006) was used at 9 days after sowing, when the seedlings showed the first clear leaf. After grafting, the seedlings were kept in a greenhouse $\left(29{ }^{\circ} \mathrm{C} \pm\right.$ 0.25 and $60 \% \mathrm{RH} \pm 0.45$ ). After 7 days of grafting, the root of the cultivar and the shoot of the rootstock were eliminated. On the eighth day after grafting, the surviving seedlings were transplanted to the field. The spacing adopted was $2.5 \mathrm{~m} \times 0.5 \mathrm{~m}$. Plants from the diploid 'Sugar Baby' cultivar were used in a 2:1 proportion, in alternate rows, as pollinators of the triploids.

The crop fertilization was carried out at 5 days prior to transplanting, based on the soil analysis and recommendations by Mendes et al. (2010), with $30 \mathrm{~kg} \mathrm{ha}^{-1}$ of $\mathrm{N}, 120 \mathrm{~kg} \mathrm{ha}^{-1}$ of $\mathrm{P}_{2} \mathrm{O}_{5}$ and $60 \mathrm{~kg} \mathrm{ha}^{-1}$ of $\mathrm{K}_{2} \mathrm{O}$ being applied, using a 06-24-12 commercial formulation of $\mathrm{N}, \mathrm{P}$ and $\mathrm{K}$, respectively. Topdressing fertilization was carried out with fertigation, using $50 \mathrm{~kg} \mathrm{ha}^{-1}$ of $\mathrm{N}$ (calcium nitrate) and $30 \mathrm{~kg} \mathrm{ha}^{-1}$ of $\mathrm{K}_{2} \mathrm{O}$ (potassium sulfate). The fertilization was performed three times a week up to 50 DAT. After the crop fertilization, the soil was covered with double-faced polyethylene (black within and white outside) to reduce weeding and maintain the soil humidity for a longer time.

After transplanting, the seedlings were placed in a low covered polypropylene tunnel, aiming at reducing the incidence of diseases at the initial development stage of the plants. At the beginning of flowering, the polypropylene was removed to allow pollination and the formation of fruits. Drip irrigation was performed and the amount of water applied daily was adjusted to the requirements of the crop, according to the climatic conditions, which were monitored by a meteorological station close to the experimental field.

Fruit harvest was carried out at 60 DAT for ungrafted 'Precious Petite' and at 70 DAT for the other plants. The incidence of wilt and death on ungrafted 'Precious Petite' plants was observed at 53 DAT, and Fusarium oxysporum was found to be responsible for it. However, the 'Precious Petite' plants grafted onto Line BGCIA 941 and the ungrafted Line BGCIA 941 survived until the end of 
the cycle, at 70 DAT. Therefore, F. oxysporum was the reason why the ungrafted treatment was harvested ten days earlier, if compared to the grafted treatment.

At transplanting, 20 plants per treatment were sampled to determine the concentration of nutrients at time ' 0 '. Subsequently, four plants per replicate were sampled for the first two samplings (10 and 20 DAT), because of the small size of the plants. But, for the subsequent samplings (30, 40, 50, 60 and 70 DAT), two plants per replicate were used. The plants were harvested without roots (cut at the base of the stem), fractionated into leaves, stem + branches and fruits (when present), and washed once under running water with detergent and again with distilled water. The samples were dried in a forced-air circulation oven at $65^{\circ} \mathrm{C}$, for 7 days. After drying, the vegetative matter was ground and digested to determine the concentration of macro and micronutrients.

The levels of $\mathrm{N}, \mathrm{P}, \mathrm{K}, \mathrm{Ca}, \mathrm{Mg}, \mathrm{S}, \mathrm{B}, \mathrm{Cu}, \mathrm{Fe}$, $\mathrm{Mn}$ and $\mathrm{Zn}$ were determined according to Embrapa (2009). Subsequently, the accumulation curves, in relation to the dry mass, were estimated in g plant $^{-1}$. The dry matter of each plant $\left(\mathrm{g}\right.$ plant $\left.{ }^{-1}\right)$ was determined by weighing the leaves, stems + branches and fruits (when present). The production of the grafted and ungrafted plants was assessed based on the number of fruits per plant and on the fruit weight $(\mathrm{kg})$, being determined in tons per hectare, considering a plant density of $5,333.33$. The following fruit quality characteristics of the grafted and ungrafted plants were examined: rind (exocarp + mesocarp) thickness $(\mathrm{cm})$, by taking four measurements of the fruit (two on the side, one in the region of the stylar scar and one at the stem region); flesh firmness $(\mathrm{N})$, by taking three readings of the fruit flesh with a manual penetrometer (FT327 model, $8.0 \mathrm{~mm}$ dial); and soluble solids
( ${ }^{\circ}$ Brix), examined in five representative fruits of the plot by taking readings at three places in the fruit flesh, using a portable optical refractometer (RFC 28 model, at $62 \%$ ).

The data were submitted to analysis of variance and the means compared by the Tukey test, at $5 \%$. When the quantitative factor was significant $(* \mathrm{p}<0.05, * * \mathrm{p}<0.01$ and $* * * \mathrm{p}<0.001)$, the variables were adjusted to logistic functions of the model: $\mathrm{Y}=\mathrm{a} /\left\{1+\mathrm{e}^{[-\mathrm{b}(\text { day-c) })}\right\}$ (Verhulst 1838), where $\mathrm{Y}=$ mean value of the examined characteristic; $\mathrm{a}=$ asymptotic maximum (maximum quantity); $b=$ mean increase rate of the accumulated quantity; day $=$ time (days); $c=$ time required to reach half of the maximum quantity.

\section{RESULTS AND DISCUSSION}

There was a significant effect of the interaction between the treatments (grafted/ungrafted) and days after transplanting, in the accumulation of dry mass and absorption of the nutrients $\mathrm{N}, \mathrm{P}, \mathrm{Ca}, \mathrm{Mg}, \mathrm{S}, \mathrm{B}$, $\mathrm{Cu}, \mathrm{Fe}$ and $\mathrm{Mn}$, in the total shoot (leaves + branches + fruits). The isolated effect of these factors was also significant. For the accumulation of $\mathrm{K}$ and $\mathrm{Zn}$, although a significant effect of the factors was found independently, there was no interaction between them (Table 1).

Until 30 DAT, the 'Precious Petite' growth was similar to that observed for 'Precious Petite' grafted onto BGCIA 941, which accumulated 58.7 g plant $^{-1}$ of dry mass. After this period, during the fruiting stage, the growth of 'Precious Petite' grafted onto BGCIA 941 (543.4 $\mathrm{g}$ plant $\left.^{-1}\right)$ was greater than that for ungrafted 'Precious Petite', from 34 to 70 DAT (Figure 1). The daily rate increased from $7 \mathrm{~g} \mathrm{plant}^{-1}$

Table 1. Summary of the analysis of variance for the accumulation of dry mass and absorption of nutrients by 'Precious Petite' with and without grafting, in relation to days after transplanting (DAT).

\begin{tabular}{|c|c|c|c|c|c|c|c|c|c|c|c|c|c|}
\hline \multirow{2}{*}{$\begin{array}{l}\text { Source of } \\
\text { variation }\end{array}$} & \multirow{2}{*}{$\begin{array}{l}\text { Degrees of } \\
\text { freedom }\end{array}$} & \multicolumn{12}{|c|}{ F values } \\
\hline & & Dry mass & $\mathrm{N}$ & $\mathrm{P}$ & $\mathrm{K}$ & $\mathrm{Ca}$ & $\mathrm{Mg}$ & $\mathrm{S}$ & $\mathrm{B}$ & $\mathrm{Cu}$ & $\mathrm{Fe}$ & $\mathrm{Mn}$ & $\mathrm{Zn}$ \\
\hline Block & 5 & $1.3^{\mathrm{ns}}$ & $1.1^{\mathrm{ns}}$ & $1.7^{\mathrm{ns}}$ & $0.8^{\mathrm{ns}}$ & $0.6^{\mathrm{ns}}$ & $1.2^{\mathrm{ns}}$ & $0.9^{\text {ns }}$ & $0.8^{\mathrm{ns}}$ & $0.8^{\mathrm{ns}}$ & $0.7^{\mathrm{ns}}$ & $1.0^{\mathrm{ns}}$ & $1.7^{\mathrm{ns}}$ \\
\hline Treatment (T) & 2 & $97.3 * *$ & $62.6^{* *}$ & $23.8^{* *}$ & $23.0 * *$ & $19.5^{* *}$ & $29.3 * *$ & $49.3 * *$ & $64.1 * *$ & $39.5 * *$ & $18.6^{* *}$ & $25.4 * *$ & * $12.3 * *$ \\
\hline Error (A) & 10 & - & - & - & - & - & - & - & - & - & - & - & - \\
\hline DAT & 7 & $237.6^{* *}$ & $129.8^{* *}$ & $107.5^{* *}$ & $136.1 * *$ & $34.6^{* *}$ & $69.9 * *$ & $153.0 * * 1$ & $117.2^{* *}$ & $100.2 * *$ & $34.2 * *$ & $34.4 * *$ & $* 9.6 * *$ \\
\hline $\mathrm{T} * \mathrm{DAT}$ & 13 & $2.2^{*}$ & $2.9 * *$ & $3.8 * *$ & $0.7^{\mathrm{ns}}$ & $2.6 * *$ & $3.9 * *$ & $4.7 * *$ & $3.6^{* *}$ & $4.3 * *$ & $3.0 * *$ & $=4.2 * *$ & $* 1.4^{\mathrm{ns}}$ \\
\hline Error (B) & 100 & - & - & - & - & - & - & - & - & - & - & - & - \\
\hline CV1 (\%) & & 22.3 & 30.9 & 60.3 & 38.81 & 51.7 & 49.3 & 36.4 & 38.8 & 39.5 & 71.5 & 56.5 & 121.1 \\
\hline CV2 (\%) & & 30.1 & 38.6 & 44.9 & 34.82 & 67.4 & 51.4 & 40.2 & 47.1 & 46.3 & 85.3 & 75.2 & 149.6 \\
\hline
\end{tabular}

$*, * *$ and ${ }^{\mathrm{ns}}$ : significant at $\mathrm{p}<0.05$ and $\mathrm{p}<0.01$ and non-significant, respectively. 
(ungrafted 'Precious Petite') to $15 \mathrm{~g} \mathrm{plant}^{-1}$ ('Precious Petite' grafted onto BGCIA 941). However, the growth of the Line BGCIA 941 was greater than that of the others up to 40 DAT, with an accumulation of 253.8 g plant $^{-1}$, during that period. Subsequently, it was surpassed by the 'Precious Petite' grafted onto Line BGCIA 941.

When watermelons start to develop, the accumulation of dry mass is usually slow, what can be related to the low absorption of water and nutrients to the small foliar area, and consequently reduces liquid carbon assimilation rates (Vidigal et al. 2009). Because the Citrullus lanatus var. citroides line showed a nutrient absorption capacity greater than the seedless cultivar (Figures 2 and 3), this cultivar logically showed a greater accumulation of dry mass during the whole cycle. This might explain the increase in dry mass for grafted 'Precious Petite'. Rouphael et al. (2008) also found a 61.2 \% increase in dry mass for watermelons grafted onto a Cucurbita spp. hybrid, when compared to ungrafted plants.

An increase in the absorption rate of macronutrients was observed after the beginning of the fruiting stage (30 DAT), when the accumulation of dry mass increased (Figure 2). In the subsequent periods (at 30-60 DAT for 'Precious Petite', 30-70 DAT for 'Precious Petite' grafted onto Line BGCIA 941 and 20-70 DAT for Line BGCIA 941), there was a high demand for all macronutrients. Therefore, these are the ideal periods for topdressing fertilization.

It was observed that nitrogen accumulation in 'Precious Petite' and 'Precious Petite' grafted

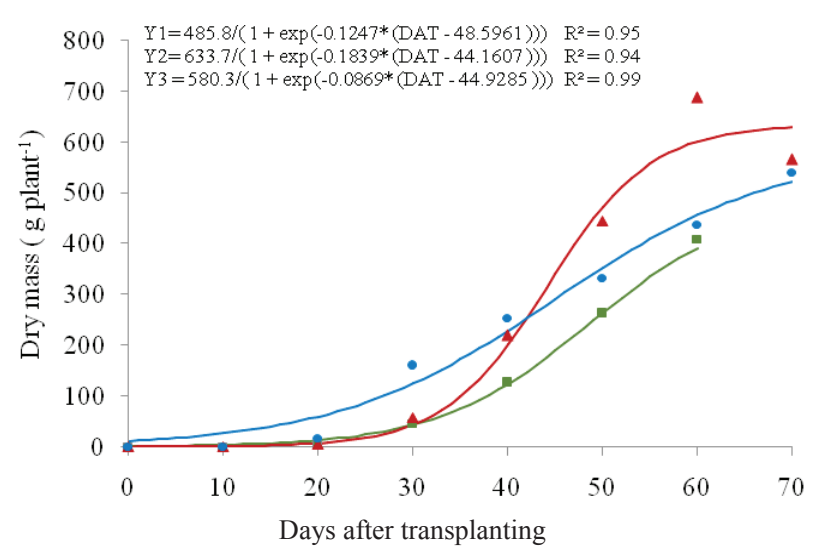

Figure 1. Accumulation of dry mass per plant of ungrafted 'Precious Petite' watermelon (-Y1), 'Precious Petite' grafted onto Line BGCIA 941 (-Y2) and Line BGCIA 941 (- $\mathrm{Y} 3$ ) rootstock, at different sampling dates. onto Line BGCIA 941 increased from 32 DAT (Figure 2a). From 38 to 70 DAT, the level of nitrogen in 'Precious Petite' grafted onto BGCIA 941 was higher than in ungrafted 'Precious Petite' and Line BGCIA 941, reaching 28 g plant $^{-1}$ at 50-60 DAT. This trend was similar to that observed for the dry mass accumulation. The period of greatest absorption of $\mathrm{N}$ was 32-60 DAT for 'Precious Petite' and 20-70 DAT for BGCIA 941, when $\mathrm{N}$ reached $15 \mathrm{~g} \mathrm{plant}^{-1}$ and 20.9 g plant $^{-1}$, respectively. The highest increase in nitrogen observed for 'Precious Petite' grafted onto Line BGCIA 941 was similar to that found by Colla et al. (2011), for 'Minirossa' watermelon grafted onto different rootstocks.

Phosphorus accumulated during the cycle for 'Precious Petite', 'Precious Petite' grafted onto Line BGCIA 941 and Line BGCIA 941 reached the greatest absorption rate at 33-60 DAT, 33-70 DAT and 30-70 DAT, respectively (Figure 2b). Phosphorus is the main nutrient involved in watermelon fruit yield, and the grafted plants in this study accumulated more phosphorus than the ungrafted ones. At 60 DAT, the accumulation of phosphorus in 'Precious Petite' grafted onto Line BGCIA 941 (1.8 g plant $\left.^{-1}\right)$ was $38.4 \%$ greater than that for 'Precious Petite'. These results differ from those observed for 'Ingrid' watermelon, which showed no difference in phosphorus accumulation between grafted and ungrafted plants (Rouphael et al. 2008). However, Yetisir et al. (2013) evaluated two watermelon cultivars grafted onto Lagenaria siceraria hybrids and Cucurbita spp. hybrids and found different amounts of phosphorus accumulation in watermelon. They also observed an influence of the rootstock and grafted cultivar on the accumulation of phosphorus.

The period of highest demand for potassium by 'Precious Petite' grafted onto Line BGCIA 941, 'Precious Petite' and Line BGCIA 941 occurred at 25-20 DAT, until the end of the cycle, when $11.1 \mathrm{~g} \mathrm{plant}^{-1}, 7.3 \mathrm{~g} \mathrm{plant}^{-1}$ and $9.0 \mathrm{~g} \mathrm{plant}^{-1}$ were respectively accumulated (Figure 2c). At 40 DAT, 50 DAT and 60 DAT, the accumulation of potassium for 'Precious Petite' grafted onto Line BGCIA 941 was greater than for 'Precious Petite'. In watermelon, potassium plays an important role in fruit quality parameters such as color, size, acidity, resistance to transport and cracking of the rind, and the 'Precious Petite' grafted onto Line BGCIA 941 plants absorbed more potassium than ungrafted 'Precious Petite'. The potassium accumulation in the present 
study differed from that for the Zaochunghongyu watermelon cultivar grafted onto Lagenaria siceraria and Cucurbita maxima $x$ Cucurbita moschata hybrids, which showed no difference in potassium accumulation, in relation to the graft (Huang et al. 2012).

From 38 DAT, 'Precious Petite' grafted onto Line BGCIA 941 absorbed more calcium than the other treatments (Figure 2d). The periods of increased calcium accumulation in 'Precious Petite', 'Precious Petite' grafted onto Line BGCIA 941 and Line BGCIA 941 were 28-60 DAT (10.1 g plant $\left.^{-1}\right)$, 28-70 DAT (12.9 g plant $^{-1}$ ) and 20-70 DAT (9.4 g plant $\left.^{-1}\right)$, respectively. The degree of calcium accumulation by the plants is related to the blossom end rot of watermelon fruits. The increase in calcium absorption by the 'Precious Petite' grafted onto Line BGCIA 941 plants might reduce the incidence of this problem,
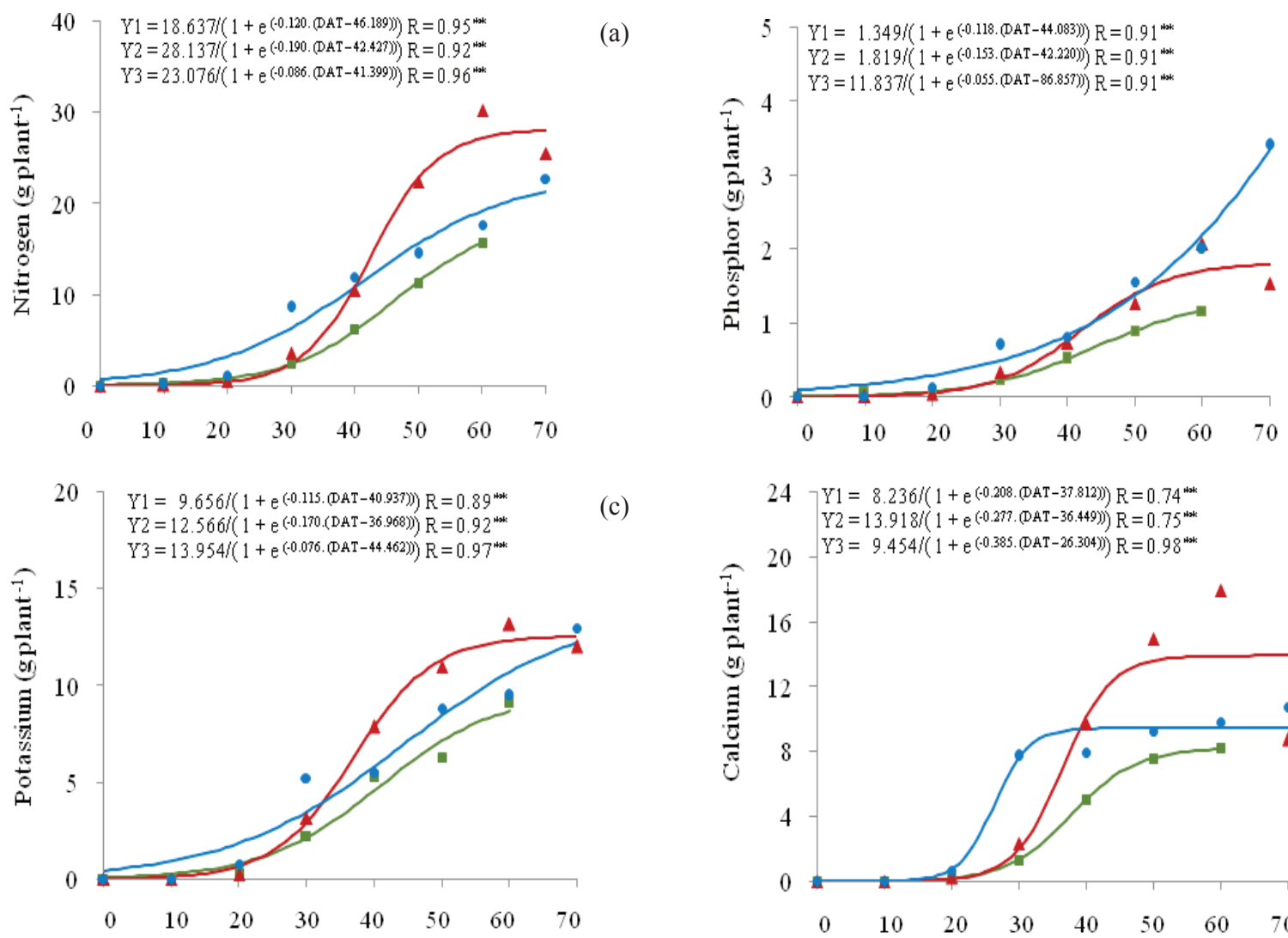

(c)
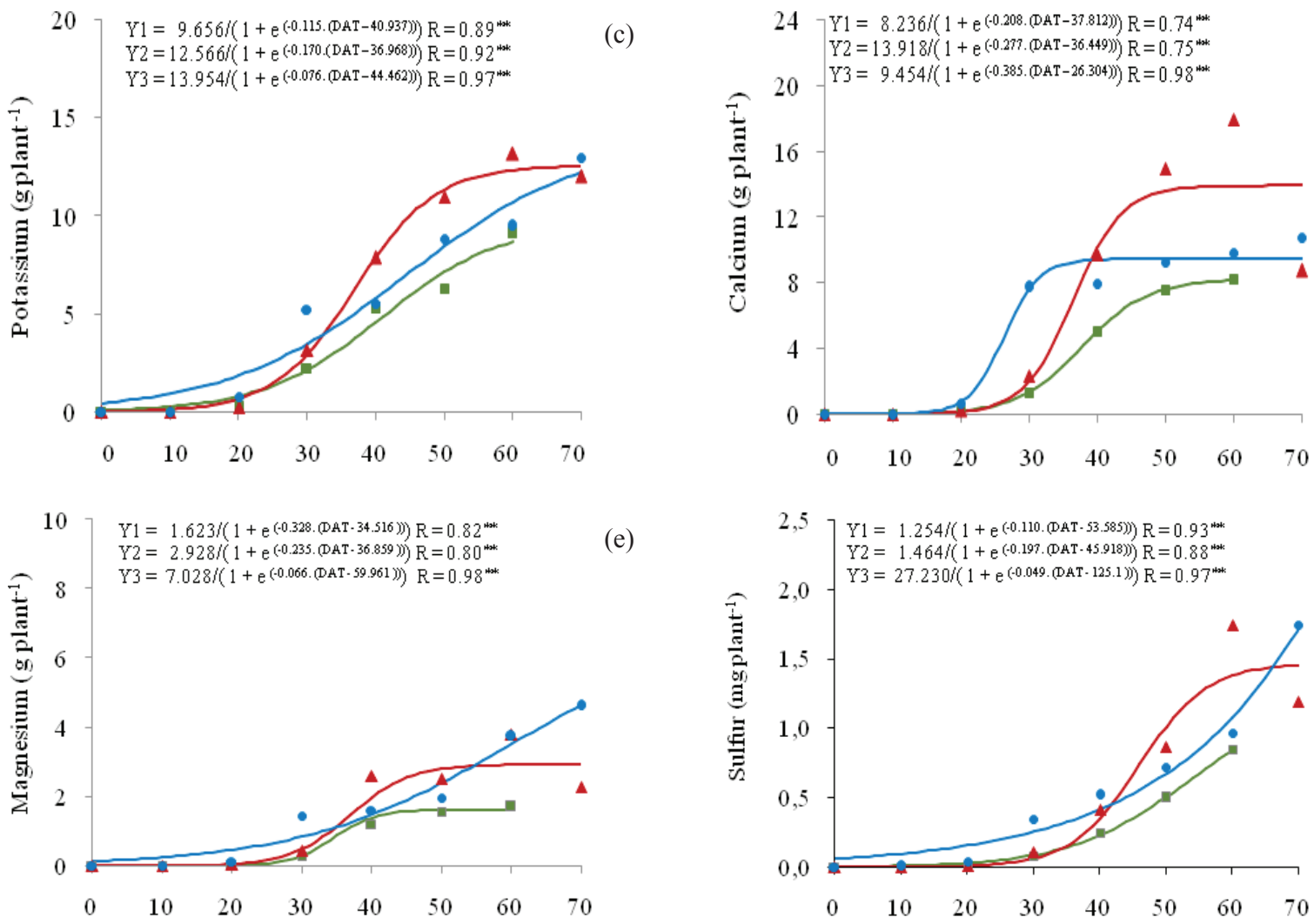

(e)

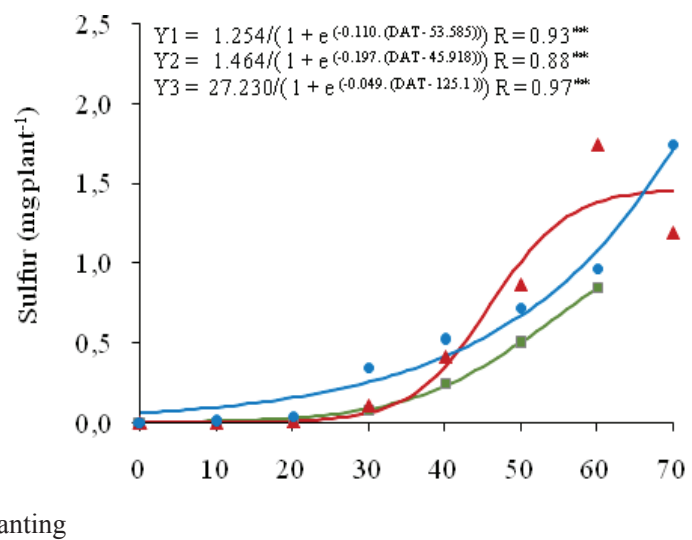

(d)

Figure 2. Accumulation of nitrogen (a), phosphorus (b), potassium (c), calcium (d), magnesium (e) and sulfur (f) in the total root of ungrafted 'Precious Petite' watermelon (-Y1), 'Precious Petite' grafted onto Line BGCIA 941 (—Y2) and Line BGCIA 941 rootstock (-Y3), at different sampling dates. 
in addition to conferring increased resistance to fruit mechanical damage. For 'Crimson Tide' and 'Crisby' watermelons, the calcium content was affected by the rootstock, regardless of the Lagenaria siceraria or Cucurbita spp. hybrids (Yetisir et al. 2013).

The period of greatest magnesium accumulation for 'Precious Petite' grafted onto Line BGCIA 941 and 'Precious Petite' occurred at 40-50 DAT, when $2.4 \mathrm{~g} \mathrm{plant}^{-1}$ and $1.3 \mathrm{~g} \mathrm{plant}^{-1}$ were respectively absorbed (Figure 2e). The absorption of magnesium was higher in 'Precious Petite' grafted onto Line BGCIA 941 at 30-45 DAT and for 'Precious Petite' at 30-40 DAT, with a daily accumulation rate of $0.23 \mathrm{~g} \mathrm{plant}^{-1}$ and $0.30 \mathrm{~g} \mathrm{plant}^{-1}$, respectively. The maximum estimated accumulation of magnesium in 'Precious Petite' grafted onto Line BGCIA 941 surpassed the 'Precious Petite'. Similar results were found by Colla et al. (2010), who used a Cucurbita spp. hybrid as rootstock. However, the use of Lagenaria siceraria as a rootstock caused no difference between the grafted plants and the ungrafted 'Ingrid' watermelon.

The greatest accumulation of sulfur occurred from 30 DAT until the end of the cycle, for 'Precious Petite' grafted onto Line BGCIA 941 and 'Precious Petite', with a maximum of $1.5 \mathrm{~g} \mathrm{plant}^{-1}$ and $0.8 \mathrm{~g} \mathrm{plant}^{-1}$ and daily accumulation of $0.197 \mathrm{~g} \mathrm{plant}^{-1}$ and 0.049 g plant $^{-1}$, respectively (Figure 2f). At 38 DAT and 60 DAT, the concentration of sulfur in 'Precious Petite' grafted onto Line BGCIA 941 was greater than that in 'Precious Petite', with 0.9 g plant $^{-1}$ and 1.7 g plant $^{-1}$, respectively.

The period of increased boron accumulation by 'Precious Petite' grafted onto Line BGCIA 941, 'Precious Petite' and Line BGCIA 941 occurred at 38-70 DAT (reaching $24.5 \mathrm{mg}$ plant $^{-1}$ ), 38-60 DAT (10.4 mg plant $^{-1}$ ) and 20-70 DAT (24.6 mg plant $^{-1}$ ), respectively (Figure 3a).

Until 38 DAT, the boron accumulation in 'Precious Petite' and 'Precious Petite' grafted onto Line BGCIA 941 was similar, but from 40 DAT and $60 \mathrm{DAT}$, the grafted plants accumulated more boron than the ungrafted ones. These results are similar to the findings for ungrafted 'Crimson Sweet' watermelon, which showed a maximum accumulation of $30 \mathrm{mg} \mathrm{plant}^{-1}$ of boron (Vidigal et al. 2009).

Until 70 DAT, 'Precious Petite' grafted onto Line BGCIA941 accumulated 4.9 mg plant $^{-1}$ of copper, with an absorption rate of $0.159 \mathrm{mg}$ plant $^{-1}$ day $^{-1}$ (Figure 3b), whereas 'Precious Petite' and Line BGCIA
941 accumulated $2.8 \mathrm{mg}$ plant $^{-1}$ and $3.6 \mathrm{mg} \mathrm{plant}^{-1}$ of copper, respectively, with an absorption rate of 0.1 plant $^{-1}$ day $^{-1}$. In contrast to the results of this study, the copper concentration for 'Ingrid' watermelon grafted onto Lagenaria siceraria and Cucurbita spp. hybrids was similar to that of the ungrafted plants (Colla et al. 2010).

At 60-70 DAT, the accumulation of iron in the total shoot was $91.0 \mathrm{mg} \mathrm{plant}^{-1}, 50.0 \mathrm{mg}$ plant $^{-1}$ and $91.8 \mathrm{mg}$ plant $^{-1}$, respectively for 'Precious Petite' grafted onto Line BGCIA 941, 'Precious Petite' and Line BGCIA 941 (Figure 3c). In this period, the accumulation of iron in 'Precious Petite' grafted onto Line BGCIA 941 was greater than in 'Precious Petite', with 3.6 mg plant $^{-1}$ at 30 DAT, 28.0 mg plant $^{-1}$ at 40 DAT, $60 \mathrm{mg} \mathrm{plant}^{-1}$ at 50 DAT and $90 \mathrm{mg} \mathrm{plant}^{-1}$ at 60 DAT. For 'Crisby' watermelon, a reduction in the concentration of iron was found when it was grafted onto Lagenaria siceraria or Cucurbita spp. hybrid, whereas for 'Crimson Tide', the response varied according to the rootstock (Yetisir et al. 2013).

From 33 DAT to 55 DAT, 'Precious Petite' grafted onto Line BGCIA 941 showed a daily accumulation rate of manganese of $0.21 \mathrm{mg} \mathrm{plant}^{-1}$, reaching a total accumulation in this period of $115 \mathrm{mg} \mathrm{plant}^{-1}$ (Figure 3d). For 'Precious Petite', a more rapid accumulation of manganese was found from 40 DAT to 60 DAT (47.1 mg plant ${ }^{-1}$ ), with $0.07 \mathrm{mg} \mathrm{plant}^{-1}$ day $^{-1}$. From 40 DAT, an increased manganese accumulation was observed for 'Precious Petite' grafted onto Line BGCIA 941, ranging from $15.8 \mathrm{mg}^{\text {plant }}{ }^{-1}$ to $67.0 \mathrm{mg}$ plant $^{-1}$ (in relation to 'Precious Petite'), and from $53.3 \mathrm{mg} \mathrm{plant}^{-1}$ to $74.6 \mathrm{mg}$ plant $^{-1}$ (considering the Line BGCIA 941). In contrast to the data obtained for 'Precious Petite' grafted onto Line BGCIA 941, for 'Ingrid' watermelon, no difference was observed in the manganese accumulation, regarding the graft (Colla et al. 2010).

At 30-60 DAT, the accumulation of zinc by the total shoot of 'Precious Petite' grafted onto Line BGCIA 941 was greater than that for 'Precious Petite' (Figure 3e). The concentration of $\mathrm{Zn}$ in 'Precious Petite' grafted onto Line BGCIA 941 increased from 34 DAT to 50 DAT, reaching an accumulation rate of $25.3 \mathrm{mg}$ plant ${ }^{-1}$. The daily accumulation rate of $\mathrm{Zn}$ for 'Precious Petite' and the Line BGCIA 941 were similar, at $0.1 \mathrm{mg} \mathrm{plant}^{-1}$ day $^{-1}$, resulting in $16.4 \mathrm{mg} \mathrm{plant}^{-1}$ and $19.6 \mathrm{mg} \mathrm{plant}^{-1}$ at the end of the cycle, respectively. On the other hand, 'Precious Petite' grafted onto Line 
BGCIA 941 had a faster accumulation. For 'Crisby' and 'Crimson Tide' watermelons, a reduction in zinc accumulation was observed with the graft onto Lagenaria siceraria and Cucurbita spp. hybrids (Yetisir et al. 2013). According to Pulgar et al. (2000), grafted watermelon plants show an increased efficiency of
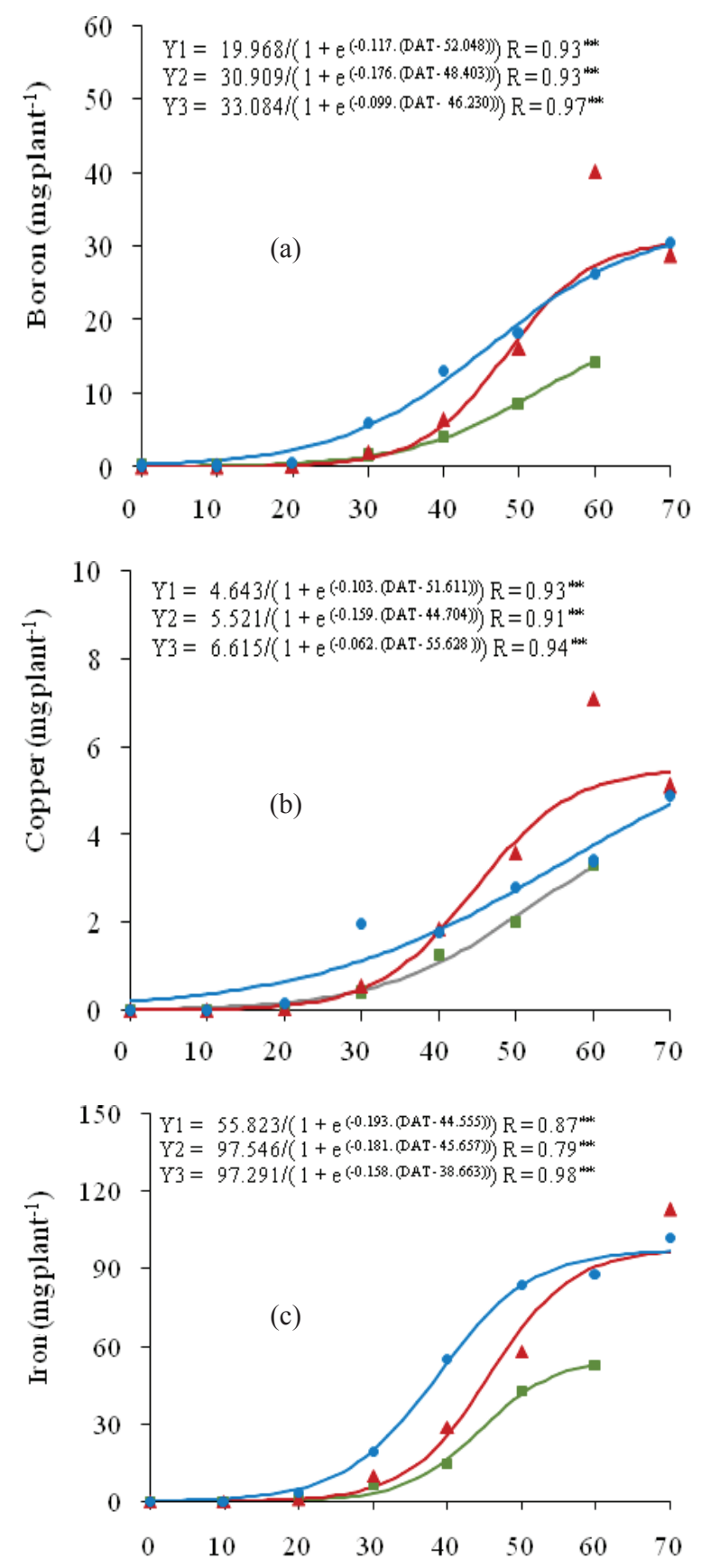

zinc integration into nitrogenous compounds, forming chelates, which may promote an increase in the foliar biomass of grafted plants.

The graft did not alter the decreasing order of macronutrient accumulation by the shoot of the plants, which was the same for 'Precious Petite' grafted onto Line BGCIA 941, 'Precious Petite' and Line BGCIA 941: $\mathrm{N}>\mathrm{K}>\mathrm{Ca}>\mathrm{Mg}>\mathrm{P}>\mathrm{S}$. However, there was a change in the order of accumulation, especially for $\mathrm{Mn}$ and $\mathrm{Fe}$, for 'Precious Petite' and 'Precious Petite' grafted onto Line BGCIA 941, and $\mathrm{Zn}$ and $\mathrm{B}$ for Line BGCIA 941 (Table 2). The observed sequence was $\mathrm{Mn}>\mathrm{Fe}>\mathrm{B}>\mathrm{Zn}>\mathrm{Cu}$ in 'Precious Petite', $\mathrm{Fe}>\mathrm{Mn}>\mathrm{Zn}>\mathrm{B}>\mathrm{Cu}$ in 'Precious Petite' grafted onto Line BGCIA 941 and $\mathrm{Fe}>\mathrm{Mn}>$ $\mathrm{B}>\mathrm{Zn}>\mathrm{Cu}$ in Line BGCIA 941.

At harvest (60 and 70 DAT), the fruits of 'Precious Petite' grafted onto Line BGCIA 941 contributed with $45.4 \%$ for the dry matter of the plant. Among the nutrients extracted by 'Precious Petite'
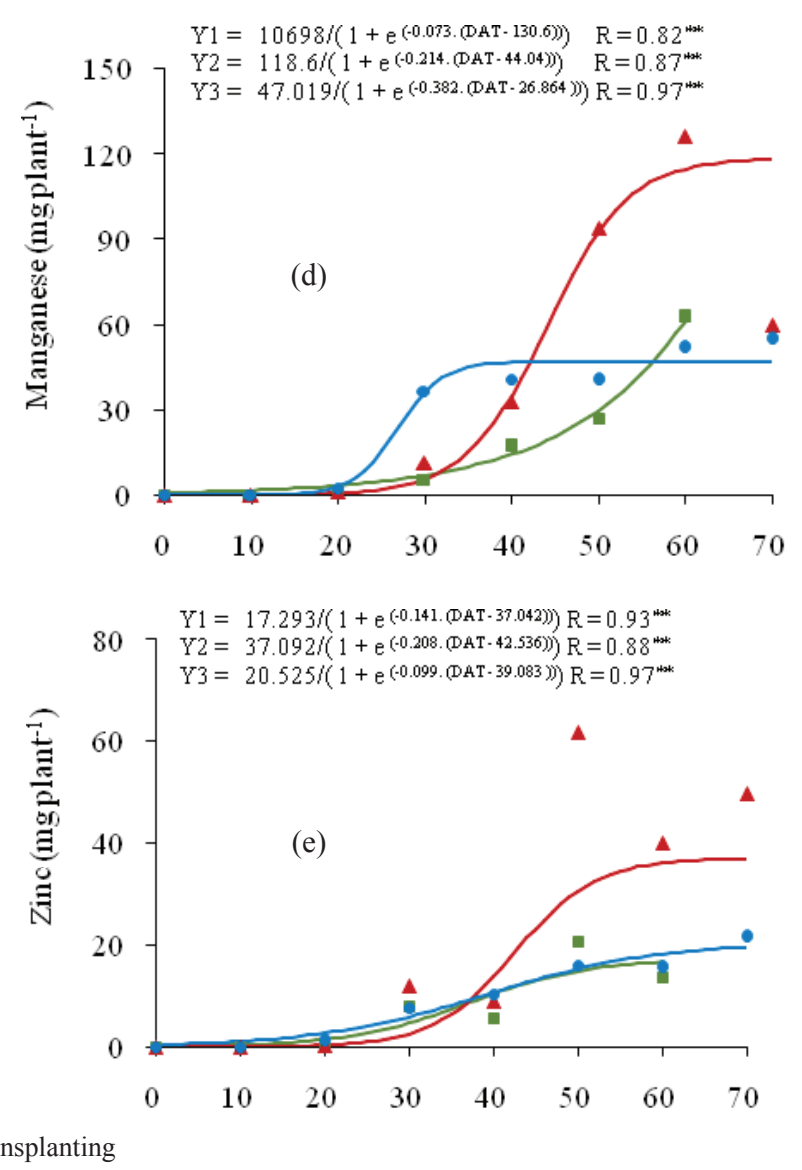

Figure 3. Accumulation of boron (a), copper (b), iron (c), manganese (d) and zinc (e) in the total shoot of ungrafted 'Precious Petite' watermelon (-Y1), 'Precious Petite' grafted onto Line BGCIA $941(-\mathrm{Y} 2)$ and Line BGCIA 941 rootstock (-Y3), at different sampling dates. 
grafted onto Line BGCIA 941, only phosphorus accumulated more in the fruits than in the vegetative parts (Table 2). There was a preferential flow of the other nutrients to the vegetative parts. This contrasts with the data for 'Precious Petite', where N, P, K, $\mathrm{S}, \mathrm{B}$ and $\mathrm{Cu}$ were accumulated more in the fruits, whereas $\mathrm{Ca}, \mathrm{Mg}, \mathrm{Fe}, \mathrm{Mn}$ and $\mathrm{Zn}$ remained in the vegetative parts.

Similarly, for the Line BGCIA 941, Ca, Mg, B, Fe and Mn had higher concentrations in the vegetative parts, whereas $\mathrm{N}, \mathrm{P}, \mathrm{K}, \mathrm{S}, \mathrm{Cu}$ and $\mathrm{Zn}$ accumulated more in the fruits (Table 2). For grafted watermelon, it is recommended that chemical fertilization is reduced by one-half or two-thirds of the recommended dose for ungrafted plants (Lee \& Oda 2010), in order to avoid excessive development of the shoots and promote a better distribution of these nutrients among the plant organs. For 'Crisby' and 'Crimson Tide' watermelons that were grafted onto Lagenaria siceraria and Cucurbita sp. hybrids, nitrogen accumulated more in the leaves than in the fruits, whereas phosphorus and zinc accumulated more in the fruits (Yetisir et al. 2013). Colla et al. (2006) found a greater accumulation of potassium in the vegetative tissues than in the fruits of the grafted plants.

There was a significant effect of the graft on the number of fruits, yield, fruit weight, rind thickness and flesh firmness, whereas the soluble solids were not affected (Table 3 ).

The number of fruits, total yield and marketable yield of 'Precious Petite' grafted onto Line BGCIA 941 were greater than that of 'Precious Petite' by $13.6 \%, 54.9 \%$ and $52.9 \%$, respectively (Table 4).

For 'Precious Petite' grafted onto Line BGCIA 941, a yield of $4.4 \mathrm{~kg} \mathrm{plant}^{-1}$ was observed, which corresponds to an increase of $62.9 \%$, when compared to the yield of 'Precious Petite' (2.7 kg plant $\left.{ }^{-1}\right)$. The graft also promoted a $36.4 \%$ reduction in the fruit weight of 'Precious Petite' (Table 4). An increase in production depending on the graft was found by Santos et al. (2014), for triploid 'RWT8154' watermelon grafted onto Citrullus sp., in agreement with the findings in this study. Similarly, the reduction in fruit weight observed for 'Precious Petite' grafted onto Line BGCIA 941 was also observed for 'Crimson Sweet' watermelon grafted onto Lagenaria

Table 2. Percentage distribution between the vegetative part and fruits of the dry mass, macro and micronutrients, at the end of the cycle, for ungrafted 'Precious Petite' watermelon (PP), 'Precious Petite' grafted onto Line BGCIA 941 (PP/BGCIA) and ungrafted BGCIA 941 (BGCIA).

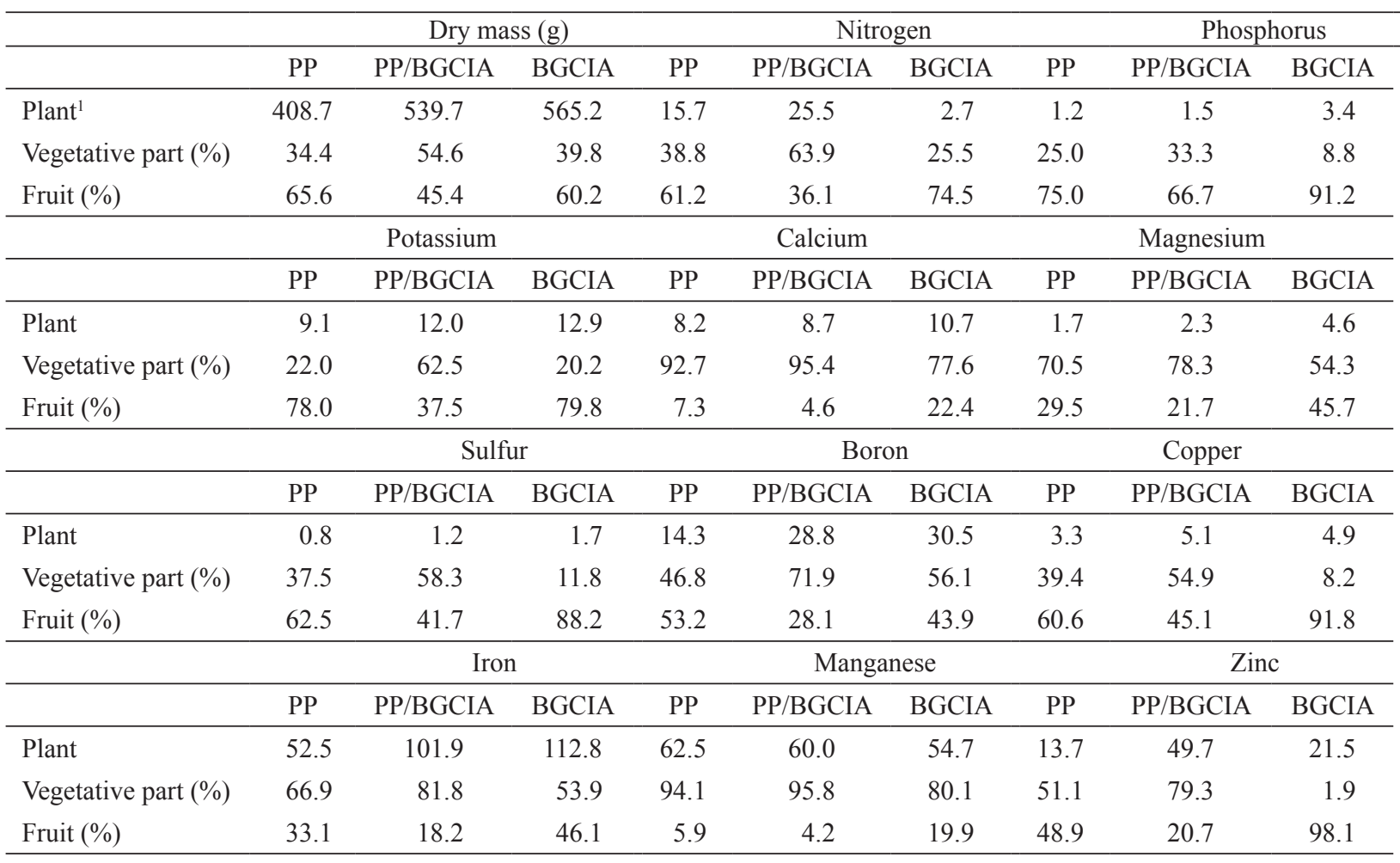

${ }^{1}$ Quantities of macro and micronutrients in the plant are expressed for grams and milligrams, respectively. 
Table 3. Summary of analysis of variance for production and quality of grafted and ungrafted watermelon fruits.

\begin{tabular}{lcccccccc}
\hline \multirow{2}{*}{$\begin{array}{c}\text { Source of } \\
\text { variation }\end{array}$} & $\begin{array}{c}\text { Degree } \\
\text { of } \\
\text { freedom }\end{array}$ & $\begin{array}{c}\text { Number } \\
\text { of fruits }\end{array}$ & $\begin{array}{c}\text { Total } \\
\text { yield }\end{array}$ & $\begin{array}{c}\text { Marketable } \\
\text { yield }\end{array}$ & $\begin{array}{c}\text { Fruit } \\
\text { weight }\end{array}$ & $\begin{array}{c}\text { Rind } \\
\text { thickness }\end{array}$ & $\begin{array}{c}\text { Flesh } \\
\text { firmness }\end{array}$ & $\begin{array}{c}\text { Soluble } \\
\text { solids }\end{array}$ \\
\hline Block & 5 & $1.5^{\text {ns }}$ & $1.4^{\text {ns }}$ & $0.5^{\text {ns }}$ & $2.0^{\text {ns }}$ & $1.2^{\text {ns }}$ & $2.7^{\text {ns }}$ & $0.3^{\text {ns }}$ \\
Treatment & 1 & $8.4^{*}$ & $6.7^{* *}$ & $28.8^{* *}$ & $2.1^{* *}$ & $193.1^{* *}$ & $110.1^{* *}$ & $0.1^{\text {ns }}$ \\
Error & 11 & - & - & - & - & - & - & - \\
\hline CV $(\%)$ & & 6.7 & 4.7 & 15.1 & 5.8 & 5.6 & 7.7 & 9.2 \\
\hline
\end{tabular}

$*, * *$ and ${ }^{\mathrm{ns}}$ significant at $\mathrm{p}<0.05$ and $\mathrm{p}<0.01$ and non-significant, respectively.

Table 4. Production characteristics and fruit quality of grafted (PP/BGCIA 941) and ungrafted (PP) triploid 'Precious Petite' watermelon.

\begin{tabular}{lccccccc}
\hline \multirow{2}{*}{ Treatment } & Fruit plant $^{-1}$ & Total yield & Marketable yield $^{1}$ & Fruit weight & Rind thickness & Flesh firmness Soluble solids \\
\cline { 2 - 8 } & Number & \multicolumn{2}{c}{ t ha $^{-1}$} & $\mathrm{~kg}$ & $\mathrm{~cm}$ & $\mathrm{~N}$ & ${ }^{\circ}$ Brix \\
\hline PP & $2.2 \mathrm{~b}$ & $15.1 \mathrm{~b}$ & $14.5 \mathrm{a}$ & $2.2 \mathrm{a}$ & $0.3 \mathrm{~b}$ & $6.2 \mathrm{~b}$ & $12.3 \mathrm{a}$ \\
PP/BGCIA 941 & $2.5 \mathrm{a}$ & $23.4 \mathrm{a}$ & $23.1 \mathrm{a}$ & $1.4 \mathrm{~b}$ & $0.5 \mathrm{a}$ & $10.1 \mathrm{a}$ & $12.2 \mathrm{a}$ \\
\hline
\end{tabular}

${ }^{1}$ Marketable yield considering a 5,333.33 plant density. Means followed by the same lower case letter differ from each other by the Tukey test (p $<0.05$ ).

siceraria, whereas 'Sugar Baby' showed a fruit weight increase with these rootstocks (Petropoulos et al. 2012).

In grafted plants, the rind thickness and flesh firmness of 'Precious Petite' increased by $66.7 \%$ and $62.9 \%$, respectively (Table 4). However, the soluble solids were unaffected. An increase in rind thickness was found for the fruits of 'Precious Petite' grafted onto Line BGCIA 941 and also for 'Crimson Tide', 'Dumara' and 'Farao' submitted to grafting (Turhan et al. 2012). The increase in rind thickness and flesh firmness are attributed to increased calcium absorption (Rouphael et al. 2010). Another hypothesis was stated by Edelstein et al. (2014), who attribute the increase in flesh firmness and rind thickness of grafted watermelon to the presence of smaller and denser cells.

\section{CONCLUSIONS}

1. 'Precious Petite' cultivar grafted onto Line BGCIA 941 accumulates more nutrients than ungrafted plants, resulting in higher fruit yield and quality.

2. The decreasing order of macronutrient accumulation in grafted and ungrafted plants was $\mathrm{N}>\mathrm{K}>$ $\mathrm{Ca}>\mathrm{Mg}>\mathrm{P}>\mathrm{S}$.

3. The micronutrient accumulation was $\mathrm{Fe}>\mathrm{Mn}>$ $\mathrm{Zn}>\mathrm{B}>\mathrm{Cu}$ for grafted 'Precious Petite' plants and $\mathrm{Mn}>\mathrm{Fe}>\mathrm{B}>\mathrm{Zn}>\mathrm{Cu}$ for ungrafted 'Precious Petite' plants.

\section{REFERENCES}

BARROS, M. M. et al. Produção e qualidade da melancia submetida à adubação nitrogenada. Revista Brasileira de Engenharia Agrícola e Ambiental, v. 16, n. 10, p. 10781084, 2012.

COHEN, S.; NAOR, A. The effect of three rootstocks on water use canopy conductance and hydraulic parameters of apple trees and predicting canopy from hydraulic conductance. Plant, Cell and Environment, v. 25, n. 1, p. 17-28, 2002.

COLLA, G. et al. Effect of salinity on yield, fruit quality, leaf gas exchange and mineral composition of grafted watermelon plants. Journal HortScience, v. 41, n. 3, p. 622-627, 2006.

COLLA, G. et al. Nitrogen-use efficiency traits of mini-watermelon in response to grafting and nitrogenfertilization doses. Journal of Plant Nutrition and Soil Science, v. 174, n. 6, p. 933-941, 2011.

COLLA, G. et al. The effectiveness of grafting to improve alkalinity tolerance in watermelon. Environment and Experimental Botany, v. 68, n. 3, p. 283-291, 2010.

CUSHMAN, K. Grafting techniques for watermelon. Gainesville: University of Florida, 2006.

EDELSTEIN, M. et al. Horticultural evaluation of exotic watermelon germplasm as potential rootstocks. Scientia Horticulturae, v. 165, n. 1, p. 196-202, 2014.

EMPRESA BRASILEIRA DE PESQUISA AGROPECUÁRIA (Embrapa). Manual de análises químicas de solos, plantas e fertilizantes. 2. ed. Brasília, DF: Embrapa Informação Tecnológica, 2009. 
HUANG, Y. et al. Grafting onto different rootstocks as a means to improve watermelon tolerance to low potassium stress. Scientia Horticulturae, v. 149, n. 1, p. 80-85, 2012.

KARACA, F. et al. Rootstock potential of Turkish Lagenaria siceraria germplasm for watermelon: plant growth, yield and quality. Turkish Journal of Agriculture and Forestry, v. 36, n. 1, p. 167-177, 2012.

LEE, J. M.; ODA, M. Grafting of herbaceous vegetable and ornamental crops. Horticultural Reviews, v. 28, n. 1, p. 61-124, 2010.

MENDES, A. M. S. et al. Adubação. In: DIAS, R. de C. S. et al. (Eds.). Sistema de produção de melancia. Petrolina: Embrapa Semiárido, 2010. Available at: $<$ https:// sistemasdeproducao.cnptia.embrapa.br/FontesHTML/ Melancia/SistemaProducaoMelancia/adubacao.htm>. Access on: Dec. 15, 2015.

PETROPOULOS, S. A. et al. Evaluation of rootstocks for watermelon grafting with reference to plant development, yield and fruit quality. International Journal of Plant Production, v. 6, n. 4, p. 481-492, 2012.

PULGAR, G. et al. Improving the mineral nutrition in grafted watermelon plants: nitrogen metabolism. Biologia Plantarum, v. 43, n. 1, p. 607-609, 2000.

RIVERO, R. M. et al. Does grafting provide tomato plants and advantages against $\mathrm{H}_{2} \mathrm{O}_{2}$ production under conditions of thermal shock? Plant Physiology, v. 117, n. 1, p. 44$50,2003$.

ROUPHAEL, Y. et al. Impact of grafting on product quality of fruit vegetables. Scientia Horticulture, v. 127, n. 8 , p. $172-179,2010$.
ROUPHAEL, Y. et al. Yield, mineral composition, water relations, and water use efficiency of grafted mini watermelon plants under deficit irrigation. HortScience, v. 43, n. 3, p. 730-736, 2008.

SANTOS, J. S. et al. Compatibilidade com porta-enxertos, rendimento e qualidade de frutos em cultivares de melancia triploide. Revista Caatinga, v. 27, n. 2, p. 141147, 2014.

TURHAN, A. et al. Influence of rootstocks on yield and fruit characteristics and quality of watermelon. Horticultural Environment and Biotechnology, v. 53, n. 4, p. 336-341, 2012.

VERHULST, P. F. Notice sur la loique la population suit dans son accroissement. Correspondance Mathématique et Physique, v. 10, n. 1, p.113-121, 1838.

VIDIGAL, S. M. et al. Crescimento e acúmulo de macro e micronutrientes pela melancia em solo arenoso. Revista Ceres, v. 56, n. 1, p. 112-118, 2009.

YETISIR, H. et al. Root-stock potential of Turkish Lagenaria siceraria germplasm for watermelon: plant growth, graft compatibility, and resistance to Fusarium. Journal of Agriculture and Forestry, v. 31, n. 4, p. 381388, 2007.

YETISIR, H. et al. Rootstocks effect on plant nutrition concentration in different organs of grafted watermelon. Agriculture Science, v. 4, n. 5, p. 230-237, 2013.

YETISIR, H.; SARI, N. Effect of different root-stock on plant growth, yield and quality of watermelon. Australian Journal of Experimental Agriculture, v. 43, n. 10, p. 1269$1274,2003$. 